\title{
EFEKTIVITAS KOMUNIKASI ANTARBUDAYA DALAM \\ MENYELESAIKAN KONFLIK RUMAH TANGGA DI \\ WILAYAH KUA LHOKSUKON
}

\begin{abstract}
Al Azhar
Dosen Program studi Ilmu Hubungan Internasional, Fakultas Ilmu Sosial dan Ilmu Politik, Universitas Al Muslim, Bireuen.
\end{abstract}

\begin{abstract}
Abstrak
Efektivitas Komunikasi Antarbudaya dalam menyelesaikan konflik di dalam rumah tangga di Kantor Urusan Agama (KUA) Lhoksukon. Tujuan dari penelitian ini adalah untuk mengetahui peran komunikasi antarbudaya masyarakat dalam menyelesaikan konflik tersebut di KUA Lhoksukon Aceh Utara dan untuk mengetahui faktor-faktor yang mempengaruhi peran komunikasi budaya masyarakat dalam menyelesaikan konflik rumah tangga di KUA Lhoksukon. Jenis penelitian yang dilakukan termasuk deskriptif kualitatif. Hasil penelitian dapat disimpulkan bahwa konflik dimotivasi oleh perbedaan karakteristik yang dibawa oleh individu dalam suatu budaya dan kebiasaan yang tidak dipahami oleh pasangan karena kebiasaan satu keluarga dengan keluarga lain selalu berbeda sehingga sikap pasangan akan menyebabkan kesalahpahaman, disebabkan karena perbedaan budaya.. Budaya dan norma yang berbeda perlu diperhatikan dan dihargai dengan menghargai norma budaya yang berbeda dapat menghindari kesalahpahaman di antara mayarakat yang ada di wilayah KUA Lhoksukon. Adat Istiadat adalah salah satu penyebab perbedaan budaya. Mencegah konflik perbedaan adat istiadat diharapkan kepsds masyarakat untuk saling menghormati. Perbedaan kebiasaan, budaya, adat istiadat terlihat pada kegiatan pesta, seperti pernikahan, khitanan, ucapan syukur, tahlilan acara atau samadiah dan lainlain. Faktor kebiasaan adalah faktor yang dipengaruhi oleh apakah orang tersebut melakukan suatu kebiasaan atau tidak. Faktor-faktor yang mempengaruhi komunikasi antarbudaya masyarakat dalam menyelesaikan konflik dengan saling menghormati perbedaan, kelompok, antarindividu, budaya, minat, sosial, fungsi hukum dan kesadaran publik.
\end{abstract}

Kata Kunci : Peran, Komunikasi, Budaya dan Konflik 


\section{A. Pendahuluan}

Adanya konflik keluarga di wilayah KUA Lhoksukon disebabkan perbedaan pendapat, kesalahpahaman, perasaan tidak nyaman, dan perasaan sensitif. Terlihat dari berkomunikasi sangat tergantung pada budayanya sebagai budaya yang berbeda-beda dari beberapa keluarga. Ada seseorang yang berbicara dengan cara yang sopan dan lembut tetapi ketika berhadapan dengan seseorang yang berbicara dengan nada tinggi, itu akan dianggap tidak memiliki tata krama. Padahal dalam kehidupan sosial kemasyarakatan ada yang terbiasa berbicara dengan nada keras dan cepat. Tidak mengherankan, ketika ada dua orang yang berbeda asal serta kebiasaan atau budaya yang berbeda bertemu dan berbicara, kemungkinan kesalahpahaman akan lebih besar. Ketika seseorang mengatakan sesuatu dengan nada tinggi, bisa jadi dari pasangannya akan menganggapnya sebagai ketidaknyamanan atau bahkan berpikir pasangannya marah padanya.

Konflik budaya dan kebiasaan terjadi dalam pernikahan, pernikahan yang terjadi antara dua orang dari daerah yang berbeda sehingga menggunakan adat pernikahan yang berbeda, tidak menggunakan 2 budaya secara bergantian dalam dalam menggunakan pakaian pengantin. Kebiasaan masyarakat yang berbeda dalam hal musyawarah dan acara adat, seperti pernikahan, ucapan syukur, tahlilan / samadiah, khitanan dan lain-lain. Dari titik ini, perbedaan budaya inilah penyebab konflik yang mengarah pada konflik yang lebih serius, dari kesalahpahaman antara pasangan dan warga masyarakat, dari norma, dan kebiasaan.

Dengan melihat uraian di atas, penulis tertarik untuk lebih menekankan dan meneliti lebih lanjut masalah secara ilmiah melalui tulisan berjudul "Efektivitas Komunikasi Antarbudaya dalam Menyelesaikan Konflik Rumah Tangga di Wilayah KUA Lhoksukon."

\section{Teori Konflik Hubungan Masyarakat (Public Relation)}

a. Definisi Konflik

Konflik adalah suatu tindakan salah satu pihak yang berakibat menghalangi, menghambat, atau mengganggu pihak lain dimana hal ini dapat terjadi antar kelompok masyarakat ataupun dalam hubungan antar pribadi.Konflik merupakan salah satu esensi dari kehidupan dan perkembangan manusia yang mempunyai karakterstik yang beragam. Manusia memiliki perbedaan jenis kelamin, strata sosial dan ekonomi, sistem hukum, bangsa, suku, agama, kepercayaan, serta budaya dan tujuan hidup yang berbeda, perbedaan inilah yang melatarbelakangi terjadinya konflik. Konflik adalah sebagai perbedaan persepsi mengenai kepentingan terjadi ketika tidak terlihat adanya alternatif. Selama masih ada perbedaan tersebut, konflik 
tidak dapat dihindari dan selalu akan terjadi. yang dapat memuaskan aspirasi kedua belah pihak. ( Wirawan, $2010: 1$ )

b. Jenis Konflik

Konflik dapat dibedakan berdasarkan posisi pelaku konflik yang berkonflik, yaitu: Konflik vertikal dan Konflik horizontal. Konflik vertikal, yaitu konflik yang terjadi antara elite dan massa (rakyat). Elit yang dimaksud adalah aparat militer, pusat pemerintah ataupun kelompok bisnis. Hal yang menonjol dalam konflik vertikal adalah terjadinya kekerasan yang biasa dilakukan oleh pemerintah terhadap rakyat.Konflik horizontal, adalah konflik terjadi di kalangan massa atau rakyat sendiri, antara individu atau kelompok yang memiliki kedudukan yang relatif sama. Artinya, konflik tersebut terjadi antara individu atau kelompok yang memiliki kedudukan relatif sederajat, tidak ada yang lebih tinggi dan rendah.

c. Faktor Penyebab Konflik

Konflik memiliki sebab yang melatarbelakangi adanya konflik atau pertentangan:

1. Perbedaan antara individu-individu

2. Perbedaan kebudayaan

3. Perbedaan kepentingan

4. Perubahan sosial

d. Akibat Konflik

Beberapa akibat yang ditimbulkan oleh pertentangan atau konflik, antara lain:

1. Bertambahnya solidaritas/in-group

2. Hancurnya atau retaknya kesatuan kelompok

3. Adanya perubahan kepribadian individu

4. Hancurnya harta benda dan jatuhnya korban manusia

e. Akomodasi Strategi Penyelesaian Konflik

Konflik dapat terjadi secara alami karena adanya kondisi obyektif yang dapat menimbulkan terjadinya konflik. Berikut ini adalah kondisi obyektif yang bisa menimbulkan konflik:

1. Tujuan yang berbeda dkemukakan oleh Hocker dan Wilmot, konflik terjadi karena pihak-pihak yang terlibat konflik mempunyai tujuan yang berbeda.

2. Komunikasi yang tidak baik.

3. Beragam karakteristik sosial.

4. Pribadi orang. 


\section{Kebutuhan.}

f. Metode Penyelesaian Konflik

Adapun metode-metode pemecahan masalah akibat konflik sosial budaya yang biasa digunakan, antara lain sebagai berikut:

1. Metode kompetisi (competition)

2. Metode menghindari (avoidance)

3. Metode akomodasi (accommodation)

4. Metode kompromi (compromise)

5. Metode kolaborasi (collaboration)

6. Metode pengurangan konflik. ( Soerjono, 2007 : 91)

\section{Definisi Komunikasi Antarbudaya}

Menyakini bahwa Komunikasi Antarbudaya adalah komunikasi yang terjadi di antara orang-orang yang memiliki kebudayaan yang berbeda (bisa beda ras, etnik, atau sosioekonomi, atau gabungan dari semua perbedaan ini. Menurut Stewart L. Tubbs, komunikasi antarbudaya adalah komunikasi antara orang-orang yang berbeda budaya (baik dalam arti ras, etnik, atau perbedaan-perbedaan sosio ekonomi). Kebudayaan adalah cara hidup yang berkembang dan dianut oleh sekelompok orang serta berlangsung dari generasi ke generasi.

1. Fungsi-Fungsi Komunikasi Antarbudaya

a. Fungsi Pribadi

Menyakini bahwa fungsi pribadi adalah fungsifungsi komunikasi yang ditunjukkan melalui perilaku komunikasi yang bersumber dari seorang individu.

1.Menyatakan Identitas Sosial

2. Menyatakan Integrasi Sosial

3. Menambah Pengetahuan

4. Melepaskan Diri atau Jalan Keluar ( Mulyana, 2007 : 42)

b. Fungsi Sosial

Fungsi sosial sebagai berikut : pengawasan, menjembatani, sosialisasi nilai dan menghibur. (Anugrah, $20017: 78$ )

c. Prinsip-Prinsip Komunikasi Antarbudaya

1. Relativitas Bahasa 
2. Bahasa Sebagai Cermin Budaya

3. Mengurangi Ketidak-pastian

4. Kesadaran Diri dan Perbedaan Antarbudaya

5. Interaksi Awal dan Perbedaan Antarbudaya

6. Memaksimalkan Hasil Interaksi

\section{d. Tujuan Komunikasi Antar Budaya}

Salah satu hal yang paling ditekankan adalah tujuan dari komunikasi antarbudaya adalah mengurangi tingkat ketidakpastian tentang orang lain. (Liliweri, $2002: 34$ )

e. Hambatan Komunikasi Antarbudaya

Hambatan-hambatan tersebut adalah: Fisik (Physical), Budaya (Cultural), Persepsi (Perceptual), Motivasi (Motivational), Pengalaman (Experiantial), Emosi (Emotional), Bahasa (Linguistic), Nonverbal dan Kompetisi (Competition)

\section{f. Konsep Komunikasi}

Komunikasi adalah suatu transaksi, proses simbolik yang menghendaki orang-orang mengatur lingkungannya dengan (1) membangun hubungan antarsesama manusia; (2) melalui pertukaran informasi; (3) untuk menguatkan sikap dan tingkah laku orang lain; serta (4) berusaha mengubah sikap dan tingkah laku itu.( Cangara, 2007 : 19)

\section{g. Konsep Dasar Budaya}

Budaya adalah keseluruhan sistem gagasan, tindakan, dan hasil karya manusia dalam rangka kehidupan masyarakat yang dijadikan milik diri manusia dengan belajar. ( Koentjaraningrat, $2000: 36$ )

\section{h. Konsep Dasar Komunikasi Antarbudaya}

Komunikasi antarbudaya merupakan komunikasi antara orang-orang yang berbeda budaya (baik dalam arti ras, etnik, atau perbedaan-perbedaan sosio ekonomi. ( Moss, 2001 : 73) 


\section{i. Definisi Konsepsional}

Peran komunikasi antar budaya masyarakat dalam menyelesaikan konflik adalah interaksi antara orang-orang yang persepsi budaya dan sistem simbolnya cukup berbeda dalam suatu komunikasi yang terjadi di antara orang-orang yang memiliki kebudayaan yang berbeda dari perbedaan kebudayaan yang berbeda bahasa, kebudayaan yang berbeda normanorma, kebudayaan yang berbeda adatistiadat dan kebudayaan yang berbeda kebiasaan.

\section{B. Metode Penelitian}

1. Jenis Penelitian

Dalam penelitian ini, penulis menggunakan penelitian deskriptif kualitatif, yaitu metode dengan prosedur pemecahan masalah yang diselidiki dengan menggambarkan atau melukiskan keadaan subyek atau obyek penelitian seseorang, pada saat sekarang berdasarkan fakta-fakta yang tampak atau sebagaimana adanya

\section{Fokus Penelitian}

Adapun fokus penelitian dari penelitian ini adalah sebagai berikut :

a. Efektivitas Komunikasi Antarbudaya dalam Menyelesaikan Konflik Rumah Tangga di Wilayah KUA Lhoksukon yang meliputi :

- Kebudayaan yang berbeda .

- Kebudayaan yang berbeda norma - norma.

- Kebudayaan yang berbeda adat-istiadat.

- Kebudayaan yang berbeda kebiasaan.

\section{Sumber Data}

Sumber Data ada dua jenis yaitu :

\section{a. Sumber Data Primer}

Sumber Data Primer yaitu Sumber data Penelitian yang di peroleh secara langsung dari sumber asli, yang berjumlah 10 orang sebagai berikut.

- Key informan ( Informasi Kunci ) Ketua RT.

- Informan lainnya yaitu masyarakat yang dilakukan secara Purposive sampling yaitu menentukan sampel dengan pertimbangan tertentu yang memberikan data secara maksimal. 


\section{b. Sumber Data Sekunder}

Sumber Data Sekunder adalah Data Penelitian yang diperoleh peneliti secara tidak langsung melalui media perantara. Data sekunder umumnya berupa bukti, catatan atau laporan historis yang telah tersusun dalam arsip. Seperti data-data yang mendukung dari buku-buku yang sudah dipublikasikan maupun yang belum dipublikasikan. Untuk menunjang penelitian ini diambil dari data-data yang berupa dokumendokumen yang berasal dari data ketua RT (rukun tetangga) di wilayah KUA Lhoksukon.

\section{Tehnik Pengumpulan Data}

Berhasil tidaknya suatu penelitian tergantung pula pada tehnik pengumpulan data yang dipergunakan, artinya apakah tehnik yang dipakai tepat atau tidak didalam mengungkapkan atau mendapatkan data seperti yang diharapkan.

Untuk mendapatkan data tersebut, maka diperlukan adanya metode tertentu dalam pengumpulan data. Adapun metode pengumpulan datanya yaitu dengan menggunakan :

a. Studi Kepustakaan (Library Research),

b. Penelitian Lapangan (Field Work Research), darinya penulis langsung mengadakan penelitian kelapangan dengan mempergunakan beberapa cara yaitu:

- Observasi

- Wawancara (interview)

- Penelitian dokumen atau dokumen research artinya penelitian terhadap seluruh dokumen atau arsip-arsip yang menyangkut Efektivitas Komunikasi Antarbudaya dalam Menyelesaikan Konflik Rumah Tangga di Wilayah KUA Lhoksukon .

5. Tehnik Analisis Data

Analisis data yang digunakan dalam penelitian ini menggunakan metode analisis data kualitatif yaitu mendeskripsikan serta menganalisis data yang diperoleh, kemudian dijabarkan dalam bentuk penjelasan yang sebenarnya.

Dalam penelitian ini penulis menggunakan teknik analisis data model interaktif dari Matthew B. Miles dan A. Michael Huberman dikutip Sugiyono yaitu analisis terdiri dari beberapa alur kegiatan yang terjadi secara bersamaan. Berikut penjelasan dari alur kegiatan dari analisis model interaktif yaitu: 

a. Pengumpulan Data
b. Reduksi Data
c. Penyajian Data
d. Penarikan Kesimpulan/Verifikasi ( Sugiyono, $2007: 15$ )

\section{Pembahasan Kebudayaan yang Berbeda}

Kebudayaan dalam perbedaan kebiasaan atau makna dibutuhkan untuk suatu kerukunan rumah tangga. Tetapi permasalahan yang terjadi dari setiap individu atau pasangan terkadang tidak mengerti kebiasaan pasangannya dan merasa tersinggung, permasalahan karena perbedaan kebiasaan yang berbeda diselesaikan dengan melibatkan orang yang dihormati(Geuchik ataupu Tuha Gampong) di Gampong tempat pasangan berada. Apabila masih bisa diselesaikan dengan musyawarah.

Beragamnya sumber konflik yang terjadi antar manusia, sulit untuk dideskripsikan secara jelas dan terperinci sumber dari konflik. Dikarenakan sesuatu yang seharusnya bisa menjadi sumber konflik, tetapi pada kelompok manusia tertentu ternyata tidak menjadi sumber konflik. Konflik yang terjadi dilatarbelakangi oleh perbedaan dalam suatu interaksi tidak bersumber dari kebiasaan saja. Perbedaan-perbedaan tersebut di antaranya menyangkut ciri fisik, kepandaian, pengetahuan, adat istiadat, keyakinan dan lainnya. Hal yang terjadi diselesaikan dengan akal sehat yang bisa di musyawarahkan antar sesama warga yang dipimpin oleh Geuchik atau tokoh masyarakat.

Dari perbedaam kebiasaan, seseorang berbicara dengan nada yang halus dan ketika berbicara dengan nada tinggi, maka akan dianggap tidak memiliki tata krama. sedangkan orang yang terbiasa berbicara dengan nada keras dan cepat. Maka ketika dua orang yang berasal dari kedua daerah ini bertemu dan berbicara, kemungkinan untuk terjadi kesalahpahaman akan lebih besar. Saat orang yang terbiasa berbicara dengan nada tinggi mengatakan sesuatu dengan nada tinggi, bisa jadi si pasangannya akan menganggapnya sebagai omelan atau bahkan mengira si pasangannya marah kepadanya. Konflik di atas diselesaikan dengan musyawarah yang diikuti dengan tokoh masyarakat dan Ketua RT yang bisa mendamaikan perbedaan kebiasaan serta budaya.

\section{Kebudayaan yang Berbeda Norma - norma}

Norma-norma yang berbeda perlu diperhatikan dan saling dihargai. Kepribadian seseorang dibentuk oleh keluarga dan masyarakat, tidak semua masyarakat memiliki nilai- 
nilai dan norma yang sama. Perbedaan norma dapat menimbulkan rasa amarah dan benci sehingga hal tersebut menimbulkan konflik.

Pasangan perlu memperhatikan norma kebudayaan yang berbeda. Pasangan perlu menghargai norma-norma kebudayaan yang berbeda-beda agar tidak terjadi kesalahpahaman di dalam rumah tangga.

Norma kebudayaan yang berbeda biasa terjadi dari faktor lingkungan, biasanya faktor lingkungan pun berperan dalam pembedaan nilai dan norma setiap daerah atau tempat. Seperti lingkungan di pasar sangat berbeda dengan lingkungan di perumahan.

\section{E. Kebudayaan yang Berbeda Adat-Istiadat}

Perbedaan budaya adat istiadat merupakan salah satu penyebab konflik, dari adat istiadat masyarakat Aceh di Lhoksukon dengan masyarakat Aceh dari daerah lain memiliki budaya dan kebiasaan yang berbeda. Perbedaan adat istiadat terlihat dari perkawinan, upacara ritual, dan hukum adat yang saling tidak mengerti antara satu sama lain menyebabkan konflik. Hal ini di atasi dengan menghargai dan menghormati antar sesama adat istiadat dan tidak saling menghina sesama perbedaan adat istiadat dan meremehkan sesama adat.

Perbedaan adat istiadat membentuk pribadi-pribadi yang berbeda. Seseorang banyak terpengaruh dengan pola pemikiran dan pendirian kelompoknya. Pemikiran dan pendirian yang berbeda itu pada akhirnya akan menghasilkan perbedaan individu yang dapat menghasilkan konflik.

Sebagai warga Lhoksukon harus menghargai antar sesama warga lain atas perbedaan adat istiadat. Biasanya perbedaan adat istiadat, suku, pandangan hidup, dan budaya, mendorong timbulnya persaingan dan pertentangan, apabila tidak dijembatani di dalam rumah tangga hal ini yang menyebabkan perbedaan pola kebudayaan.

\section{F. Kebudayaan yang berbeda kebiasaan}

Kebiasaan merupakan faktor yang dipengaruhi oleh sering tidaknya salah seseorang itu melaksanakan suatu pekerjaan. Kebudayaan yang berbeda kebiasaan terlihat dari perbedaan individu. Konflik di dalam rumah tangga sering terjadi dari faktor perbedaan kepribadian antar individu, biasanya perbedaan individu yang menjadi sumber konflik dari perbedaan pendirian dan perasaan. Orang memiliki pendirian dan perasaan yang berbedabeda satu dengan lainnya. Perbedaan pendirian dan perasaan akan sesuatu hal atau lingkungan yang nyata ini dapat menjadi faktor penyebab konflik, sebab dalam menjalani 
hubungan keluarga, seseorang tidak selalu sejalan dengan pasangannya.Orang akan terpengaruh dengan pola-pola pemikiran dan pendiriannya.

Pemikiran dan pendirian yang berbeda itu pada akhirnya akan menghasilkan perbedaan individu yang dapat menghasilkan konflik.

\section{G. Faktor-faktor yang mempengaruhi Efektivitas Komunikasi Antarbudaya dalam Menyelesaikan Konflik Rumah Tangga di Wilayah KUA Lhoksukon.}

Faktor-faktor yang merupakan efektivitas komunikasi antarbudaya dalam menyelesaikan konflik rumah tangga harus menghargai dan menghormati pasangan masingmasing. Adanya perbedaan budaya serta kebiasaan dapat dijembatani dalam hal penyelesaikan konflik yang ada dan tidak akan menimbulkan konflik antara budaya yang satu dengan yang lainnya.

Dalam efektivitas penyelesaikan konflik diharapkan sesama pasangan seharusnya masing-masing pihak dalam suatu konflik bersedia untuk melepaskan atau mengurangi tuntutannya masing-masing, tidak berbeda pendapat, tidak salah paham, tidak ada pihak yang dirugikan, dan yang terlibat tidak memiliki perasaan yang sensitif. Sehingga warga atau masyarakat melalui Geuchik dan Peutua Gampong harus dapat menjembatani perbedaan budaya secara berbudaya, karena perasaan masing-masing pihak memicu ketidak nyamanan jika tidak diselesaikan secara bijaksana. Dampak konflik lainnya adalah mengundang turun tangan keluarga dan saudaranya yang datang membantu keluarganya secara menyelesaikan permasalahan yang akan berujung perpisahan..

\section{H. PENUTUP}

Berdasarkan pada penyajian data dan analisis data yang telah diuraikan sebelumnya, maka dapat dikemukakan kesimpulan antara lain :

1. Permasalahan pasangan keluarga yang mengalami konflik terjadi dari setiap individu atau kelompok, karena budaya yang berbeda harus diselesaikan dengan melibatkan orang yang dihormati atau sebagai tokoh masyarakat di wilayah Lhoksukon dengan cara musyawarah. Penggunaan adat dan budaya yang penuh kesantunan menjadi penting untuk mengurangi kesalahpahaman.

2. Kebudayaan yang berbeda norma-norma perlu diperhatikan dan dihargai. Pasangan keluarga dan masyarakat perlu menghargai norma-norma kebudayaan yang berbedabeda agar tidak terjadi kesalahpahaman antar pasangan keluarga yang ada di wilayah 
KUA Lhoksukon. Norma kebudayaan yang berbeda biasa terjadi dari faktor lingkungan tempat tinggal.

3. Adat Istiadat merupakan salah satu penyebab perbedaan budaya. Perbedaan budaya adat-istiadat perlu dihargai dan dihormati. Mencegah suatu konflik perbedaan adat istiadat diharap pasangan keluarga dan masyarakat saling menghargai antara satu sama lain. Perbedaan budaya adat istiadat nampak pada berlangsungnya pesta, misalnya acara pernikahan, khitanan, syukuran, acara tahlilan dan lain-lain.

4. Kebiasaan adalah faktor yang dipengaruhi oleh sering tidaknya orang itu melaksanakan suatu pekerjaan. perasaan akan sesuatu hal atau lingkungan yang nyata ini dapat menjadi faktor penyebab konflik sosial, sebab dalam menjalani hubungan sosial, seseorang tidak selalu sejalan dengan pasangan serta kelompoknya.

5. Faktor-faktor yang dapat menyelesaikan konflik dari masyarakat harus menghargai dan menghormati sesama individu, masing-masing pihak dalam suatu konflik bersedia untuk melepaskan atau mengurangi tuntutannya masing-masing, tidak berbeda pendapat, tidak salah paham, tidak ada pihak yang dirugikan, seluruh pasangan serta masyarakat tidak memiliki perasaan yang sensitif, tidak merusak dan tidak melibatkan keluarga yang harus turun tangan dengan saudaranya untuk membantu secara menyelesaikan persoalannya.

Setelah melalui penelitian sederhana, dengan rendah hati penulis merasa perlu untuk memberikan saran-saran yang mungkin bermanfaat kepada semua pihak. Adapun saran-saran yang akan penulis kemukakan adalah sebagai berikut :

1. Diharapkan pasangan keluarga menjaga interaksi dengan menghargai dan menghormati perbedaan budaya serta kebiasaan.

2. Diharapkan agar pasangan keluarga dan masyarakat perlu menghargai norma-norma kebudayaan yang berbeda-beda agar tidak terjadi kesalahpahaman antar sesama.

3. Seluruh masyarakat Lhoksukon saling menghormati perbedaan budaya adat-istiadat untuk mencegah suatu konflik dan mengefektivkan peran komunikasi antarbudaya dalam menyelesaikan atas konflik yang ada.

4. Bagi pasangan keluarga diharapkan tidak mengikuti perasaan secara sepihak dalam menghadapi konflik di dalam keluarga dan menjadikan masalah berkepanjangan.

5. Diharapkan seluruh pasangan keluarga dan masyarakat harus menghargai dan menghormati sesama walaupun berbeda secara budaya, tidak salah paham, tidak ada pihak yang dirugikan, tidak merusak hubungan silaturahmi yang ada dan tidak menggunakan amarah. 


\section{DAFTAR PUSTAKA}

Alijoyo, Antonius \& Subarto Zaini, Komisaris Independen: Penggerak Praktik GCG di perusahaan, Jakarta : PT. Indeks, 2004.

Anugrah, Dadan, Komunikasi Antarbudaya. Jakarta: Jala Permata. A. 2007.

Cangara, Hafied, Pengantar Ilmu Komunikasi, Jakarta: PT. Raja Grafindo Persada, 2007.

Koentjaraningrat, Pengantar Ilmu Antropologi. Jakarta: Rineka Cipta, 2000.

Liliwei, Alo, Dasar-dasar Komunikasi Antarbudaya, Yogyakarta, PT. Pustaka Pelajar, 2002.

Mulyana, Dedy, Ilmu Komunikasi: Suatu Pengantar. Bandung: Remaja Rosdakarya, 2007.

Soekanto, Soerjono, Sosiologi Suatu Pengantar, Jakarta: PT. Raja Grafindo Persada, 2007.

Stewart L. Tubbs-Sylvia Moss, Human Communication. Bandung : Remaja rosda karya, 2001.

Sugiyono, Metode Penelitian Kuantitatif, Kualitatif, R\&D, Bandung: lfabeta, 2007.

Wirawan, Konflik dan Manajemen Konflik (Teori, Aplikasi, dan Penelitian). Jakarta: Salemba Humanika, 2010. 